\title{
Estimation of total leaf area and D leaf area of pineapple from biometric characteristics
}

\author{
Marlúcia Pereira dos Santos ${ }^{1}$, Victor Martins Maia ${ }^{2}$, Fernanda Soares Oliveira ${ }^{3}$, \\ Rodinei Facco Pegoraro ${ }^{4}$, Silvânio Rodrigues dos Santos², Ignacio Aspiazú ${ }^{2}$
}

\begin{abstract}
The estimation of pineapple total leaf area by simple, fast and non-destructive methods allow inferences related to carbon fixation estimative, biotic and abiotic damages and correlating positively with yield. The objective was to estimate D leaf area and total leaf area and of 'Pérola' pineapple plants from biometric measurements. For this purpose, 125 slips were selected and standardized by weight for planting in pots. Nine months after planting in a greenhouse, the plants were harvested to evaluate the total leaf area of the plant, D leaf area and D leaf length and width using a portable leaf area meter. Pearson correlation analysis was made and it was observed significative positive and strong correlation among the studied variables. Then, regression models were adjusted. It was observed that the D leaf area of 'Pérola' pineapple can be estimated from the length and width of this same leaf and the total leaf area can be estimated from the D leaf area.

Index terms: Ananas comosus var. comosus, correlation, biometry, 'Pérola'.
\end{abstract}

\section{Estimativa da área foliar total e da área da folha do abacaxizeiro a partir de características biométricas}

Corresponding author: marlucia.jaibes@yahoo.com.br

Received: July 11, 2017.

Accepted: February 15, 2018.

Copyright: All the contents of this journal, except where otherwise noted, is licensed under a Creative Commons Attribution License.

\begin{abstract}
Resumo - A estimativa da área foliar total do abacaxizeiro por métodos simples, rápidos e não destrutivos permite inferências relacionadas à aferição da fixação de carbono, danos bióticos e abióticos, além de correlacionar-se com a produtividade. Objetivou-se estimar a área da folha $\mathrm{D}$ e a área foliar total do abacaxizeiro 'Pérola' a partir de medidas biométricas. Para tanto, foram selecionadas 125 mudas tipo filhote com pesos padronizados, para plantio em vasos. Nove meses após o plantio em casa de vegetação, as plantas foram colhidas para avaliar-se a área foliar total da planta, a área foliar da folha $\mathrm{D}$, o comprimento e a largura da média folha $\mathrm{D}$ com o auxílio de um medidor portátil de área foliar. Por meio da análise de correlação de Pearson, foi observada correlação significativa, positiva e forte entre as variáveis estudadas. Em seguida, foram ajustados modelos de regressão. Observou-se que a área foliar da folha $\mathrm{D}$ do abacaxizeiro 'Pérola' pode ser estimada a partir do comprimento e da largura desta mesma folha e, a área foliar total pode ser estimada a partir da área da folha D.

Termos para indexação: Ananas comosus var. comosus, correlação, biometria, 'Pérola'.
\end{abstract}


Leaf area is an important attribute in the evaluation of photosynthetic efficiency of plants, as well as for the analysis of plant growth (WERADUWAGE et al., 2015). Growth and productivity are directly related to total leaf area. In several cultivated species, higher values of leaf area reflect in higher yields (KOESTER et al., 2004; SILVA et al., 2015, WERADUWAGE et al., 2015). Therefore, the determination of this characteristic allows to make inferences about the growth and the expected productivity.

Leaf area estimation can be done using indirect and direct methods. Indirect methods are based on the determination of leaf area as a function of linear leaf dimensions. For this, it is necessary to measure the length, or width and / or the product of the length by the width of the leaves, followed by determination of the actual leaf area. Afterwards, models are generated and validated that estimate the leaf area as a function of these measures. Based on these models, it is possible to measure linear dimensions of the leaves in the field and to estimate the area in different stages of growth and development, without the need to destroy the plants (CARGNELUTTI FILHO et al., 2015).

For pineapple plants, literary informations regarding leaf area estimation by non-destructive and indirect methods are still scarce (FRANCISCO et al., 2014). However, if these data are available, the vegetative growth and appropriate time for adopting cultural practices in pineapple farming may be determined by the leaf area estimated from mathematical models.

In other species, such as Smallanthus sonchifolius (ERLACHER et al., 2016) and Brassica napus L. var. oleifera (TARTAGLIA et al., 2016), mathematical models were developed to estimate leaf area, so that length and width are the independent variables of the equation that serve as inputs to the observed values estimating the value of the dependent variable. These mathematical models can be used to estimate leaf area in different regions and cultivation conditions since the allometric measurements are collected in loco.

The determination of leaf area in response to different agroecosystems and climatic conditions can help technical assistance and producers to improve management practices in order to explore the genetic potential of each cultivar (ZANON et al., 2015). In addition, it makes research that need plant growth evaluations more efficient and cheaper. Therefore, the objective of the present study was to estimate the total leaf area and D leaf area of 'Pérola' pineapple using biometric measurements.

The experiment was carried out in a chapel greenhouse. Data from the indoor environment were collected from daily readings of a thermohygrometer, which recorded an average temperature of $29.6^{\circ} \mathrm{C}$ and a mean relative humidity of $57.1 \%$.
Slips of the pineapple cultivar Pérola were collected in a field and underwent a cicatrization period, being exposed to the sun, with the base facing upwards for approximately 15 days. Then they were taken to the laboratory, washed and stored at room temperature for another 15 days. In this phase, 125 slips were selected according to their weight uniformity $(80.50 \pm 31.68 \mathrm{~g})$, for planting in pots filled with sand. The distribution of the pots with the slips in the greenhouse was done randomly.

During the conduction of the experiment, the slips were fertilized with nutrient solution proposed by Hoagland and Arnon (1950). Fertilization with the nutrient solution was done twice a week, with approximately 48 $\mathrm{mL}$ per application.

The plants were cultivated for a period of nine months. After this, the pineapples were removed from the pots for the following evaluations: D leaf length (DLL) and D leaf width (DLW), D leaf area (DLA) and total plant leaf area (TPLA). The D leaf width was obtained in the median region of the leaf. To obtain these measurements, a portable leaf area meter, model LI-3000C, was used.

From these data, using the Sigma Plot 12.0 software, a Pearson correlation analysis was performed, adjusting, then, equations to estimate the $\mathrm{D}$ leaf area from the measurements of length and width of this leaf, as well as the total plant leaf area from the D leaf area.

Pearson correlation was significant and positive among all the studied characteristics. The highest correlation coefficient values observed were 0.78 and 0.90 between DLL and DLW in relation to DLA, respectively, and 0.82 between TLA and DLA.

A multiple linear model was fitted $(\mathrm{P}<0.001)\left(\mathrm{R}^{2}\right.$ $=0.97)$, allowing to estimate the area of the $\mathrm{D}$ leaf as a function of the DLL and DLW measurements, according to the following equation:

$$
\operatorname{DLA}\left(\mathrm{cm}^{2}\right)=-214,727+(2,938 \times \mathrm{DLL})+(74,329
$$

$x$ DLW);

In which:

DLA $=$ pineapple D leaf area $\left(\mathrm{cm}^{2}\right)$

$\mathrm{DLL}=\mathrm{D}$ leaf length $(\mathrm{cm})$

DLW $=$ D leaf width $(\mathrm{cm})$

Likewise, a linear model was fitted to estimate the total leaf area of the pineapple $\left(\mathrm{R}^{2}=0.68\right)$ in the vegetative phase as a function of the D leaf area (Figure 1).

TLA $\left(\mathrm{cm}^{2}\right)=363,1281+17,4297$ AFFD;

in which:

TLA $=$ total leaf area of the pineapple plants $\left(\mathrm{cm}^{2}\right)$

The $\mathrm{D}$ leaf is considered to be the most metabolically active in the plant, reflecting the actual nutritional state and productive capacity of the pineapple (VILELA et al., 2015), being the most important from the point of view of crop management. For being a reference leaf and easily detached from the plants without harming its development, it was used to obtain the allometric measurements 
(FRANCISCO et al., 2014), in order to estimate the total leaf area of the plant. The results found in the present study confirm that the D leaf of pineapple plants should be used as a reference for several analyzes and decision making, since it has relation with the total leaf area of the plant and, consequently, with its light interception capacity.

The leaf length and leaf width values were adequate to estimate leaf area, because through these biometric characteristics a mathematical equation was proposed. Establishing this relationship involved destructive analysis of the leaves. This process was only necessary to determine the allometric relationships. Once this mathematical expression has been established, the leaf area in other studies or works can be estimated without separating the leaves, using only a ruler or a pocket measuring tape to obtain the length and width of the median region of the $\mathrm{D}$ leaf or, if available, a portable or tabletop leaf area meter using values only from the D leaf area. Similar results were observed in a study of clonal varieties of Coffea canephora (SCHMILDT et al., 2015).

Total leaf area of 'Vitória' pineapple plants can also be estimated by equation, using the length and width measurements of the D leaf (FRANCISCO et al., 2014). In this work, these authors observed that the leaf area of 'Vitória' plants can be estimated with the following equation: $\mathrm{LA}=19,298 \times(\mathrm{L} \times \mathrm{W})-559,9$; in which: $\mathrm{LA}=$ leaf area $\left(\mathrm{cm}^{2}\right), \mathrm{L}=$ leaf length $\mathrm{D}(\mathrm{cm})$ and $\mathrm{W}=$ leaf width $\mathrm{D}(\mathrm{cm})$. Although these authors indicate that this equation can be used for other commercial pineapple cultivars, such as 'Pérola' and 'Smooth Cayenne', the ideal and more recommended is that the use of these models is specific for a cultivar. This explains the differences in the models fitted between the present study and the mentioned work, and is justified by the differences in morphology and growth behavior and inherent production of each cultivar that are observed under commercial and experimental conditions (PEGORARO et al., 2014; MAIA et al., 2016).

In the present work, the maximum value of total leaf area estimated was about $8,000 \mathrm{~cm}^{2}$, while Francisco et al. (2014) estimated values close to $10,000 \mathrm{~cm}^{2}$ for the 'Vitória' cultivar, which reinforces the differences between pineapple cultivars and the need to use specific models.

The anatomical characteristics of pineapple leaves make it difficult to calculate leaf area, so these proposed equations are an alternative to estimate leaf area of 'Pérola' pineapple plants in a simple, fast, reliable and cheap way.

The leaf is the main place of occurrence of photosynthesis and the main source of photoassimilates for the other organs of the plant. The photosynthetic surface increases with the development of leaf area, also resulting in a greater accumulation of dry matter in the plant. There is a significant and positive correlation between leaf area and shoot dry matter, stem dry matter and fruit mass of 'Pérola' pineapple plants (MELO et al., 2006). Therefore, the exact determination of the leaf area is important for agronomic studies such as the estimation of crop water requirements, potential evapotranspiration, transpiration, photosynthesis, among others (PADRÓN et al., 2016), besides being widely described as a variable which indicates productivity.

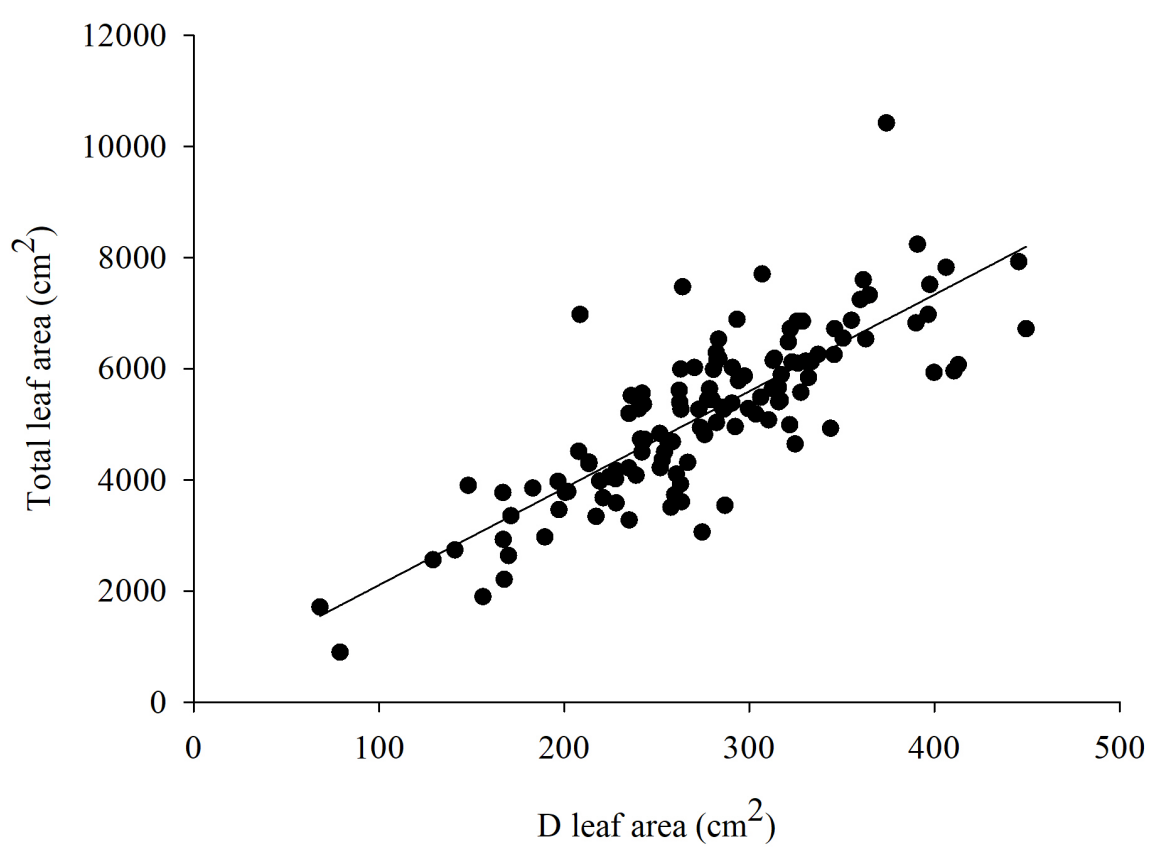

Figure 1 - Total leaf area $\left(\mathrm{cm}^{2}\right)$ as a function of D leaf area $\left(\mathrm{cm}^{2}\right)$ of 'Pérola' pineapple plants, Janaúba-MG, 2017. 
Therefore, the D leaf area $\left(\mathrm{cm}^{2}\right)$ of 'Pérola' pineapple plants can be estimated from the length and width of this same leaf and the total leaf area $\left(\mathrm{cm}^{2}\right)$ of 'Pérola' pineapple plants can be estimated from the D leaf area.

\section{Acknowledgements}

The authors thank the Minas Gerais Research Support Foundation (FAPEMIG), the National Council for Scientific and Technological Development (CNPq), the Coordination for the Improvement of Higher Education Personnel (CAPES) for grants and financial support.

\section{References}

CARGNELUTTI FILHO, A.C.; TOEBE, M.; ALVES, B.M.; BURIN, C. Estimação da área foliar de feijão guandu por dimensões foliares. Ciência Rural, Santa Maria, v.45, n.1, p.1-8, 2015. Disponível em: $\leq \mathrm{http}: / / \mathrm{www}$. scielo.br/pdf/cr/v45n1/0103-8478-cr-45-01-00001.pdf $>$. Acesso em: 21 out. 2017.

ERLACHER, W.A.; OLIVEIRA, F.L.; FIALHO, G.S.; SILVA, D.M.N.; CARVALHO, A.H.O. Models for estimating yacon leaf area. Horticultura brasileira, Brasília, DF, v.34, n.3, p.422-427, 2016. Disponível em: <http://www.scielo.br/pdf/hb/v34n3/1806-9991hb-34-03-00422.pdf $>$. Acesso em: 21 out. 2017.

FRANCISCO, J.P.; DIOTTO, A.V.; FOLEGATTI, M.V.; SILVA, L.D.B.; PIEDADE, S.M.S. Estimativa da área foliar do abacaxizeiro cv. Vitória por meio de relações alométricas. Revista Brasileira de Fruticultura, Jaboticabal, v.36, n.2, p.285-293, 2014.

HOAGLAND, D.R.; ARNON, D.I. The water culture method for growing plants without soils. Berkeley: California Agricultural Experimental Station, 1950. $347 \mathrm{p}$.

KOESTER, R.P.; SKONECZKA, J.A.; CARY, T.R.; DIERS, B.W.; AINSWORTH, E.A. Historical gains in soybean (Glycine max Merr.) seed yield are driven by linear increases in light interception, energy conversion, and partitioning efficiencies. Journal of Experimental Botany, Oxford, v.65, n.12, p.3311-3321, 2014.

MAIA, V.M.; OLIVEIRA, F.S.; PEGORARO, R.F.; SOUZA, B.A.M.; FERREIRA, L.B.; ASPIAZÚ, I. Vegetative growth stages of irrigated 'Pérola' pineapple. Acta Horticulturae, The Hague, v.1111, p.275-280, 2016.

MELO, A.S.; NETTO, A.O.A.; DANTAS NETO, J.; BRITO, M.E.B.; VIÉGAS, P.R.A.; MAGALHÃES, L.T.S.; FERNANDES, P.D. Desenvolvimento vegetativo, rendimento da fruta e otimização do abacaxizeiro cv. Pérola em diferentes níveis de irrigação. Ciência Rural,
Santa Maria, v.36, n.1, p.93-98, 2006.

PADRÓN, R.A.R.; LOPES, S.J.; SWAROWSKY, A.; CERQUERA, R.R.; NOGUEIRA, C.U.; MAFFEI, M.Non-destructive models to estimate leaf área on Bell pepper crop. Ciência Rural, Santa Maria, v.46, n.11, p.1983-1944, 2016. Disponível em: $<$ http://www.scielo.br/ $\mathrm{pdf} / \mathrm{cr} / \mathrm{v} 46 \mathrm{n} 11 / 1678-4596-\mathrm{cr}-46-11-01938 . \mathrm{pdf}>$. Acesso em: 16 out. 2017.

PEGORARO, R.F.; SOUZA, B.A.M.S.; MAIA, V.M.; AMARAL, U.; PEREIRA, M.C.T. Growth and production of irrigated vitória pineapple grown in semi-arid conditions. Revista Brasileira de Fruticultura, Jaboticabal, v.36, n.3, p.693-703, 2014.

SCHMILDT, E.R.; AMARAL, J.A.T.; SANTOS, J.S.; SCHMILDT. Allometric model for estimating leaf área in clonal varieties of coffe (Coffea canephora). Revista Ciência Agronômica, Fortaleza, v.46, n.4, p.740-748, 2015. Disponível em: $\leq \mathrm{http}: / /$ www.scielo.br/pdf/rca/ v46n4/0045-6888-rca-46-04-0740.pdf $>$. Acesso em: 21 out. 2017.

SILVA, M.R.; MARTIN, T.N.; PAVINATO, P.S.; BRUM, M.S. Estimativas da necessidade de nitrogênio para produção de grãos e silagem de milho. Revista Caatinga, Mossoró, v.28, n.3, p.12-24, 2015. Disponível em: <http://www.scielo.br/pdf/rcaat/v28n3/1983-2125rcaat-28-03-00012.pdf $>$. Acesso em: 21 out. 2017.

TARTAGLIA, F.L.; RIGHI, E.Z.; ROCHA, L.; LOOSE, L.H.; MALDANER, I.C.; HELDWEIN, A.B. Nondestructive models for leaf area determination in canola. Revista Brasileira de Engenharia Agrícola e Ambiental, Campina Grande, v.20, n.6, p.551-556, 2016. Disponível em: $<$ http://www.scielo.br/pdf/rbeaa/v20n6/1415-4366rbeaa-20-06-0551.pdf $>$. Acesso em: 21 out. 2017.

VILELA, G.B.; PEGORARO, R.F.; MAIA, V.M. Predição de produção do abacaxizeiro 'Vitória'por meio de características fitotécnicas e nutricionais. Revista Ciência Agronômica, Fortaleza, v.46, n.4, p.724-732, 2015.

WERADUWAGE, S.M.; CHEN, J.; ANOZIE, F.C.; MORALES, A.; WEISE, S.E.; SHARKEY, T.D. The relationship between leaf area growth and biomass accumulation in Arabidopsis thaliana. Frontiers in Plant Science, Melbourne, v.6, p.167, 2015. Disponível em: $\leq$ https://doi.org/10.3389/fpls.2015.00167>. Acesso em: 21 jan. 2018.

ZANON, A.J.; STRECK, N.A.; RICHTER, G.L.; BECKER, C.C.; ROCHA, T.S.M.; CERA, J.C.; WINCK, J.E.M.; CARDOSO, A.P.; TAGLIAPIETRA, E.L.; WEBER, P.S. Contribuição das ramificações e a evolução do índice de área foliar em cultivares modernas de soja. Bragantia, Campinas, 2015. Disponível em: $<$ http://www.scielo.br/pdf/brag/2015nahead/0006-8705brag-167844990463.pdf $>$. Acesso em: 24 out. 2017. 